\title{
Sex-related differences in clinicopathological features and survival of patients with primary urethral carcinoma: a population-based study
}

This article was published in the following Dove Press journal:

OncoTargets and Therapy

10 July 2017

Number of times this article has been viewed

\author{
Yong Wei* \\ Yu-Peng Wu* \\ Ning $X^{*}$ \\ Xiao-Dong $\mathrm{Li}$ \\ Shao-Hao Chen \\ Hai Cai \\ Qing-Shui Zheng \\ Xue-Yi Xue
}

Department of Urology, First Affiliated Hospital of Fujian Medical University, Fuzhou, China

*These authors contributed equally to this work
Correspondence: Xue-Yi Xue;

Qing-Shui Zheng

Department of Urology, First

Affiliated Hospital of Fujian Medical

University, 20 Chazhong Road, Fuzhou,

Fujian 350005, China

Tel +8659l 8798 I687

Email uroxxy@163.com;

urologyfujian@163.com
Purpose: To analyze the Surveillance, Epidemiology, and End Results (SEER) database to determine the effects of sex and prognostic factors on the survival of patients with primary urethral carcinoma (PUC).

Materials and methods: We selected 453 patients diagnosed with PUC from 2004 to 2013 from the SEER database. Statistical analysis was used to identify sex-specific differences associated with tumor characteristics and cancer-specific survival (CSS) and overall survival (OS).

Results: Compared with men, there was a higher proportion of black women, more negative lymph-node status, higher American Joint Committee on Cancer (AJCC) stage, more advanced T3 stage, more with adenocarcinoma (Ac), and fewer with squamous cell carcinoma (SCC) or transitional cell carcinoma (TCC). Among women, black race and M1 stage were associated with shorter CSS and OS, respectively. In addition, surgery was associated with longer OS in women. Among men, AJCC III and IV and M1 stages were associated with shorter CSS and OS. In addition, age $>75$ years associated with shorter OS in men.

Conclusion: Black race was associated with shorter OS and CSS of women, and surgery was associated with longer OS of women. Among men, AJCC stage III and IV were associated with shorter OS and CSS. Age $>75$ years was associated with shorter OS in men only. Women with Ac experienced poor CSS compared with men. Men with TCC experienced worse CSS compared with those with Ac or SCC.

Keywords: sex, prognostic, survival, transitional cell carcinoma, adenocarcinoma, squamous cell carcinoma

\section{Introduction}

Primary urethral carcinoma (PUC) is a relatively rare disease that accounts for approximately $1 \%$ of all malignancies. ${ }^{1,2}$ Sex may represent a risk factor associated with diagnosis or treatment. For example, evidence indicates that women present with more advanced $\mathrm{T}$ stages and higher tumor grades than men. ${ }^{3}$ Insufficient information is available about sex-related disparities associated with clinicopathological features and survival of patients with PUC. ${ }^{4}$ Therefore, there is controversy about the contribution of sex differences to survival and prognosis. ${ }^{5-7}$ The purpose of the present study was to address this question. For this purpose, we analyzed patients' records acquired from the Surveillance, Epidemiology, and End Results (SEER) database. ${ }^{8}$ 


\section{Materials and methods}

\section{Ethical standards}

Permission was obtained to access research-data files (reference 12256-Nov2015). This study was approved by the ethics committee of the First Affiliated Hospital of Fujian Medical University. All information from the SEER database has been deidentified. Informed consent is not required for use of SEER data, as was confirmed by the ethics committee.

\section{Patients}

Patients diagnosed with PUC (ICD-O-3 code 68.0) between 2004 and 2013 were identified within the SEER database $(n=866)$. The SEER database consists of 18 population-based cancer registries that represent approximately $28 \%$ of the US population. ${ }^{9}$ The selected subjects' characteristics were comparable with those of the SEER database and general population. ${ }^{3}$ Exclusion criteria were as follows: patients not certified according to primary international guidelines, individuals recommended for radiation without records, cancer-specific surgery unknown, only death certificate available, microscopic focus or foci only and no size of focus, and unknown race. After the exclusions, we analyzed the records of 453 patients. The search criteria was set as "sequence number = one primary only" to truly identify patients for survival analysis who had only had one malignant primary in their lifetimes. Therefore, PUC was defined as patients who had only had UC in their lifetimes without bladder or upper urinary tract urothelial carcinoma.

\section{Statistical analysis}

Clinicopathological features were compared across groups using Pearson's $\chi^{2}$. Fisher's exact tests were also used where available. The Kaplan-Meier method was used to generate survival curves. Log-rank tests were used to analyze the differences between curves. Univariate and multivariate Cox hazard analyses were used to determine factors correlated with cancer-specific survival (CSS) and overall survival (OS). Data were analyzed using the $\mathrm{R}$ statistical package (http://www.r-project.org). Two-sided $P<0.05$ was considered to indicate statistical significance. ${ }^{10}$

\section{Results}

Subjects comprised 453 patients diagnosed with PUC between 2004 and 2013 (Table 1). When patients were stratified according to sex, statistically significant differences emerged (Table 1). More men than women were white $(82.2 \%$ vs $61.4 \%$, respectively; $P<0.001)$. However, fewer men than women were black $(12.2 \%$ vs $30.1 \%$,
Table I Characteristics of patients

\begin{tabular}{|c|c|c|c|}
\hline & $\begin{array}{l}\text { Women (\%), } \\
n=166\end{array}$ & $\begin{array}{l}\text { Men (\%), } \\
n=287\end{array}$ & $\begin{array}{l}\text { Total (\%), } \\
n=453\end{array}$ \\
\hline Median survival, months (IQR) & $20(9-44.8)$ & $21(8-43)$ & $20(9-44)$ \\
\hline \multicolumn{4}{|l|}{ Year of diagnosis } \\
\hline 2004-2008 & $87(52.4)$ & $150(52.3)$ & $237(52.3)$ \\
\hline $2009-2013$ & $79(47.6)$ & 137 (47.7) & $216(47.7)$ \\
\hline \multicolumn{4}{|l|}{ Age at diagnosis, years } \\
\hline $0-54$ & $30(18.1)$ & $61(21.3)$ & $91(20.1)$ \\
\hline $55-64$ & $43(25.9)$ & $59(20.6)$ & $102(22.5)$ \\
\hline $65-74$ & $42(25.3)$ & $65(22.6)$ & $107(23.6)$ \\
\hline $75-84$ & $31(18.7)$ & $70(24.4)$ & $101(22.3)$ \\
\hline $85+$ & $20(12)$ & $32(11.1)$ & $52(11.5)$ \\
\hline \multicolumn{4}{|l|}{ Race } \\
\hline White & $102(6 \mid .4)$ & $236(82.2)$ & $338(74.6)$ \\
\hline Black & $50(30.1)$ & $35(12.2)$ & $85(18.8)$ \\
\hline Others & $14(8.4)$ & $16(5.6)$ & $30(6.6)$ \\
\hline \multicolumn{4}{|l|}{ Marital status } \\
\hline Not married & $99(59.6)$ & $88(30.7)$ & I87 (4I.3) \\
\hline \multicolumn{4}{|l|}{ common law) } \\
\hline Unknown & $9(5.4)$ & $15(5.2)$ & $24(5.3)$ \\
\hline \multicolumn{4}{|l|}{ Grade } \\
\hline Grade I and grade II & $58(34.9)$ & $73(25.4)$ & |3| (28.9) \\
\hline Grade III & $63(38)$ & $96(33.4)$ & $159(35.1)$ \\
\hline Grade IV & $22(13.3)$ & $67(23.3)$ & $89(19.6)$ \\
\hline Unknown & $23(13.9)$ & 51 (17.8) & $74(16.3)$ \\
\hline \multicolumn{4}{|l|}{ Tumor size, cm } \\
\hline$\leq 2$ & $23(13.9)$ & $26(9.1)$ & $49(10.8)$ \\
\hline$>2$ and $\leq 5$ & $40(24.1)$ & $65(22.6)$ & $105(23.2)$ \\
\hline$>5$ & I4 (8.4) & $34(11.8)$ & $48(10.6)$ \\
\hline Unknown & $89(53.6)$ & $162(56.4)$ & $25 \mathrm{I}(55.4)$ \\
\hline \multicolumn{4}{|l|}{ Positive-node status } \\
\hline 0 & $30(18.1)$ & $25(8.7)$ & $55(12.1)$ \\
\hline$I-3$ & $22(13.3)$ & $28(9.8)$ & $50(\mathrm{II})$ \\
\hline$>3$ & 0 & $7(2.4)$ & $7(1.5)$ \\
\hline Unknown & II4 (68.7) & $227(79.1)$ & $34 \mid(75.3)$ \\
\hline \multicolumn{4}{|l|}{ AJCC stage } \\
\hline I & $38(22.9)$ & $73(25.4)$ & III (24.5) \\
\hline II & 23 (I3.9) & $56(19.5)$ & 79 (17.4) \\
\hline III and IV & $94(56.6)$ & $119(4 \mid .5)$ & $213(47)$ \\
\hline Unknown & II (6.6) & $39(13.6)$ & $50(\mathrm{II})$ \\
\hline \multicolumn{4}{|l|}{ pT stage } \\
\hline TO and TI & $43(25.9)$ & $9 \mid$ (3I.7) & $134(29.6)$ \\
\hline $\mathrm{T} 2$ & 31 (18.7) & $85(29.6)$ & $116(25.6)$ \\
\hline T3 & $57(34.3)$ & $44(15.3)$ & 101 (22.3) \\
\hline $\mathrm{T} 4$ and $\mathrm{TX}$ & $35(21.1)$ & $67(23.3)$ & $102(22.5)$ \\
\hline \multicolumn{4}{|l|}{ pN stage } \\
\hline No & I I 8 (7I.I) & $195(67.9)$ & $3 \mid 3(69.1)$ \\
\hline NI & $21(12.7)$ & $36(12.5)$ & $57(12.6)$ \\
\hline N2 & $16(9.6)$ & $26(9.1)$ & $42(9.3)$ \\
\hline$N X$ & II (6.6) & $30(10.5)$ & $4 I$ (9.I) \\
\hline \multicolumn{4}{|l|}{ pM stage } \\
\hline Mo & I43 (86.I) & $234(8 \mid .5)$ & $377(83.2)$ \\
\hline MI & $17(10.2)$ & 34 (II.8) & 51 (II.3) \\
\hline$M X$ & $6(3.6)$ & $19(6.6)$ & $25(5.5)$ \\
\hline \multicolumn{4}{|l|}{ Surgery } \\
\hline No & $60(36.1)$ & $77(26.8)$ & $137(30.2)$ \\
\hline Yes & $106(63.9)$ & $210(73.2)$ & $316(69.8)$ \\
\hline
\end{tabular}


Table I (Continued)

\begin{tabular}{llll}
\hline & $\begin{array}{l}\text { Women (\%), } \\
\mathbf{n = 1 6 6}\end{array}$ & $\begin{array}{l}\text { Men (\%), } \\
\mathbf{n = 2 8 7}\end{array}$ & $\begin{array}{l}\text { Total (\%), } \\
\mathbf{n}=\mathbf{4 5 3}\end{array}$ \\
\hline $\begin{array}{l}\text { Radiation } \\
\text { Yes }\end{array}$ & $69(41.6)$ & $67(23.3)$ & $136(30)$ \\
No & $97(58.4)$ & $220(76.7)$ & $317(70)$ \\
Histological type & & & \\
SCC, NOS & $52(31.3)$ & $113(39.4)$ & $165(36.4)$ \\
$\begin{array}{l}\text { TCC, NOS } \\
\text { Ac, NOS }\end{array}$ & $54(32.5)$ & $148(51.6)$ & $202(44.6)$ \\
\hline
\end{tabular}

Abbreviations: AJCC, American Joint Committee on Cancer; SCC, squamous cell carcinoma; TCC, transitional cell carcinoma; Ac, adenocarcinoma; NOS, not otherwise specified.

respectively; $P<0.001)$. Moreover, the incidence of unmarried women was higher than men $(59.6 \%$ vs $30.7 \%$, respectively; $P<0.001)$. The incidence of married women was lower than married men $(34.9 \%$ vs $64.1 \%$, respectively; $P<0.001)$. Fewer women than men had been diagnosed with grade IV PUC ( $13.3 \%$ vs $23.3 \%$, respectively; $P=0.016$ ). Lymph nodes were not detected in $18.1 \%$ of women and $8.7 \%$ of men $(P=0.002)$. Further, American Joint Committee on Cancer (AJCC) stage III and IV was more frequent among women than men $(56.6 \%$ vs $41.5 \%$, respectively; $P=0.007)$. More women presented with stage T3 than men $(34.3 \%$ vs $15.3 \%$, respectively; $P<0.001$ ). Women underwent surgery less frequently than men $(63.9 \%$ vs $73.2 \%$, respectively; $P=0.038$ ), and radiation was administered more frequently to women than men ( $41.6 \%$ vs $23.3 \%$, respectively; $P<0.001)$. Transitional cell carcinoma (TCC) was the most common histological type among all patients. When patients were stratified according to sex, there were fewer women with TCC than men (32.5\% vs $51.6 \%$, respectively; $P<0.001)$.

Kaplan-Meier analysis revealed that women and men experienced similar CSS ( $P=0.787$, Figure $1 \mathrm{~A})$ and OS $(P=0.809$, Figure 1B). The median CSS rates were 63 and 52 months for men and women, respectively, and their respective 5-year CSS rates were $52.52 \%$ and $44.89 \%$. The median OS rates of men and women were 32 months and 39 months, respectively, and their respective 5-year OS rates were $38.52 \%$ and $35.88 \%$.

However, adenocarcinoma (Ac) was associated with worse prognosis of CSS only in women ( $P=0.0185$, Figure 2$)$. Further, TCC predicted a worse prognosis of men only for CSS compared with Ac ( $P=0.0297$, Figure 3$)$ or squamous cell carcinoma (SCC; $P=0.0175$, Figure 4).

Univariate analysis revealed that marital status, AJCC stage, $\mathrm{pT}$ stage, $\mathrm{pN}$ stage, $\mathrm{pM}$ stage, and surgery were independent prognostic factors of OS for men and women and that race and grade were independent prognostic factors of OS for women. Compared with women, year of diagnosis, age at diagnosis, and histological type were independent prognostic factors of OS of men. Marital status, grade, AJCC stage, $\mathrm{pT}$ stage, $\mathrm{pN}$ stage, $\mathrm{pM}$ stage, and surgery were

B

A Cancer-specific survival

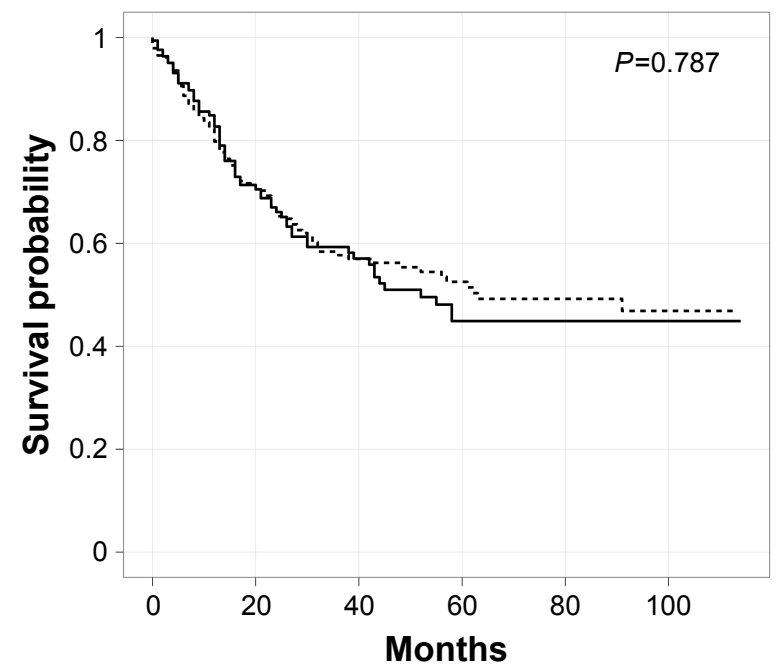

Numbers at risk

$\begin{array}{lllllll}\text { Women } & 166 & 84 & 50 & 27 & 21 & 12\end{array}$

$\begin{array}{lllllll}\text { Men } & 287 & 150 & 77 & 51 & 32 & 13\end{array}$

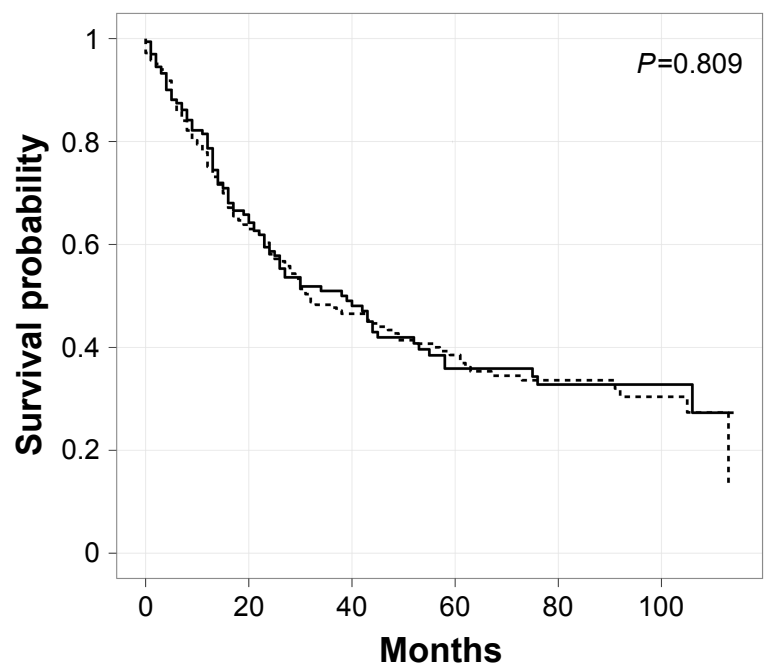

Numbers at risk

$\begin{array}{lllllll}\text { Women } & 166 & 84 & 50 & 27 & 21 & 12\end{array}$

$\begin{array}{llllll}\text { Men } & 287 & 150 & 77 & 51 & 32\end{array}$

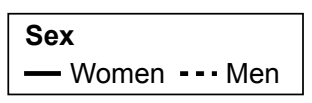

Figure I Kaplan-Meier plots of cancer-specific survival (A) and overall survival (B) of women and men. 


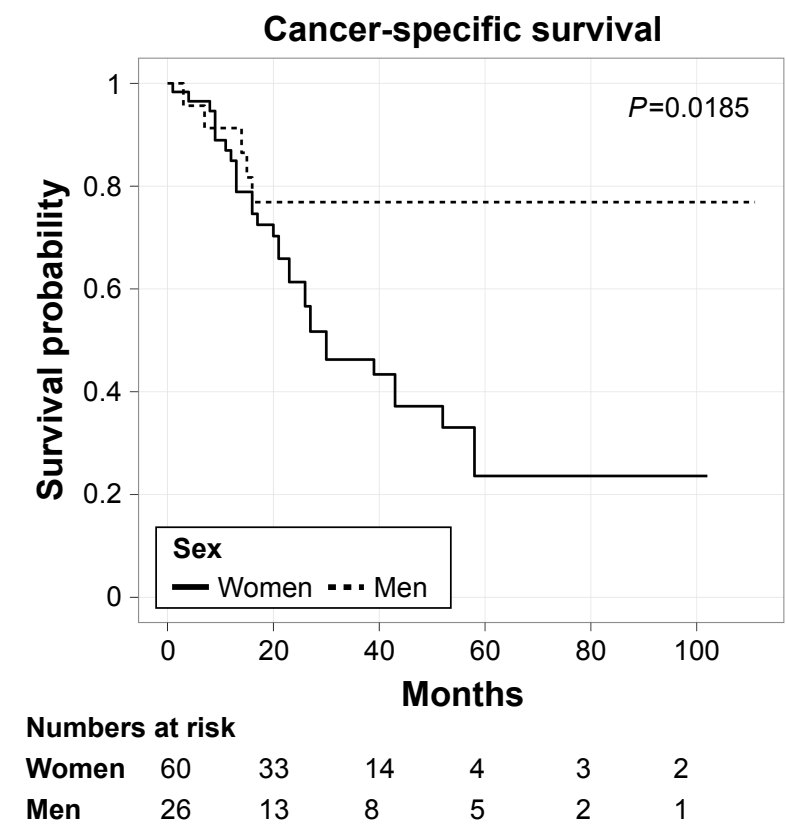

Figure 2 Kaplan-Meier plots of cancer-specific survival of adenocarcinoma stratified by sex.

independent prognostic factors of CSS of women and men. Race and histological type were significantly associated with CSS in women and men, respectively. Interestingly, the prognostic factors associated with OS of women were concordant with CSS. However, compared with the OS of men, year of diagnosis and age at diagnosis were not significantly associated with CSS. Grade was significantly associated with CSS of men, but not OS.

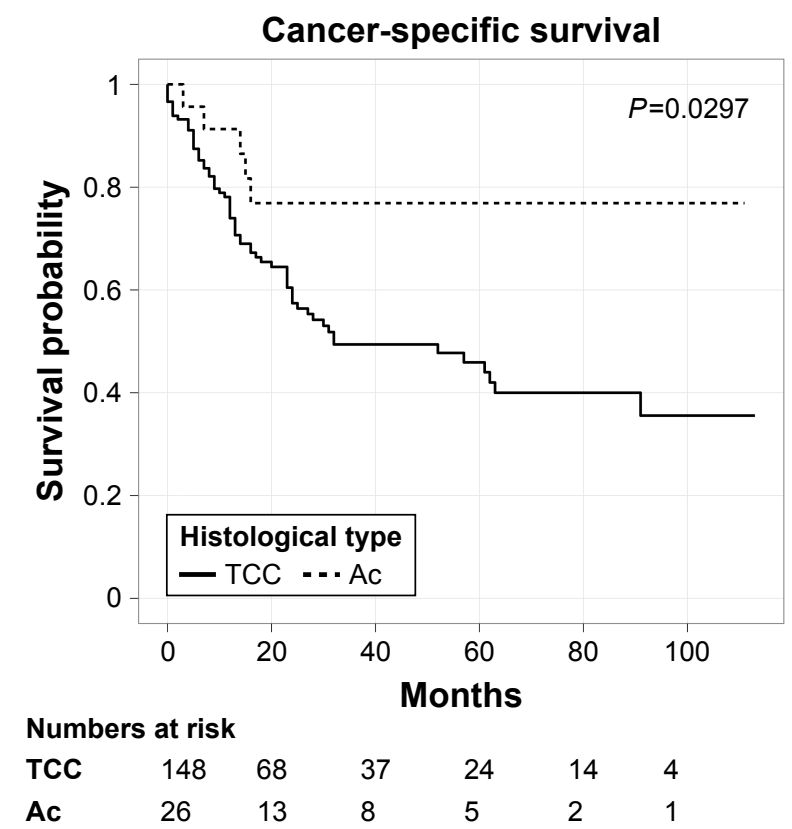

Figure 3 Kaplan-Meier plots of cancer-specific survival in men patients stratified by transitional cell carcinoma (TCC) and adenocarcinoma (Ac).

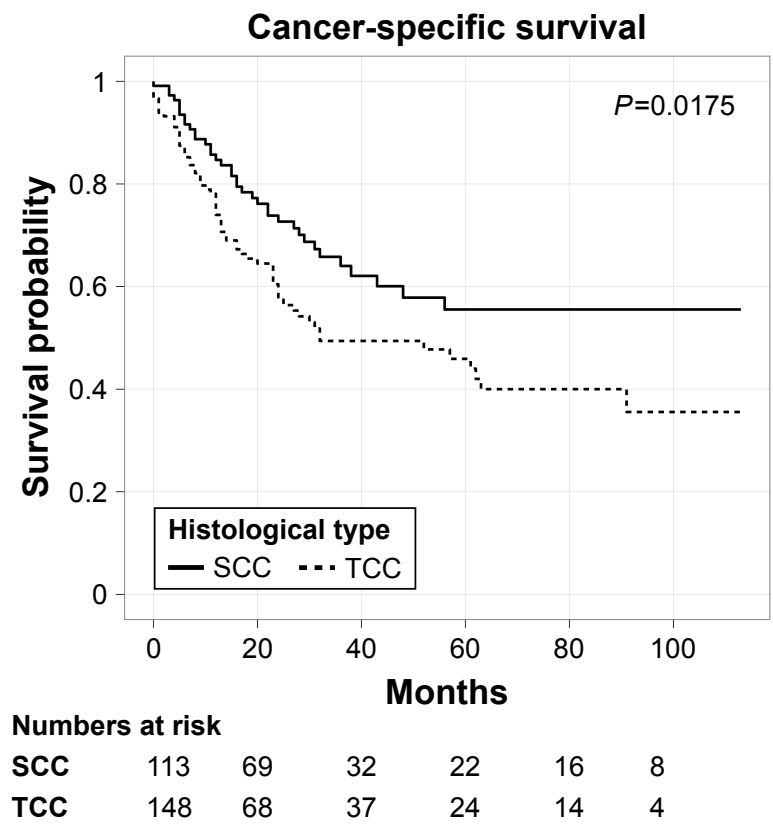

Figure 4 Kaplan-Meier plots of cancer-specific survival in men patients stratified by transitional cell carcinoma (TCC) and squamous cell carcinoma (SCC).

Potential prognostic factors were further evaluated using multivariate analysis (Tables 2-5). After other prognostic factors were adjusted, we found that black race was associated with shorter OS and CSS of women, and surgery was associated with longer OS of women. Among men, AJCC stage III and IV were associated with shorter OS and CSS. Age $>75$ years was associated with shorter OS in men only.

\section{Discussion}

PUC is a relatively rare cancer that accounts for $<1 \%$ of all malignancies, ${ }^{2}$ and there are certain differences between clinicopathological findings for women and men with PUC. ${ }^{2-4,11,12}$ Here, we utilized SEER data to investigate the differences in clinicopathological characteristics and survival between women and men, and we evaluated prognostic factors as well.

Table 2 Univariate and multivariate analysis of overall survival in women

\begin{tabular}{|c|c|c|c|c|}
\hline & \multicolumn{2}{|c|}{ Univariate analysis } & \multicolumn{2}{|c|}{ Multivariate analysis } \\
\hline & HR (95\% Cl) & $P$-value & HR (95\% Cl) & $P$-value \\
\hline \multicolumn{5}{|c|}{ Year of diagnosis } \\
\hline 2004-2008 & Reference & & & \\
\hline $2009-2013$ & $0.7(0.43-1.13)$ & 0.14 & & \\
\hline \multicolumn{5}{|c|}{ Age at diagnosis, years } \\
\hline $0-54$ & Reference & & & \\
\hline $55-64$ & $0.7 \mid(0.34-1.45)$ & 0.35 & & \\
\hline $65-74$ & $1.1(0.55-2.18)$ & 0.79 & & \\
\hline $75-84$ & $1.45(0.74-2.84)$ & 0.28 & & \\
\hline $85+$ & $1.76(0.84-3.68)$ & 0.14 & & \\
\hline
\end{tabular}

(Continued) 
Table 2 (Continued)

\begin{tabular}{|c|c|c|c|c|}
\hline & \multicolumn{2}{|c|}{ Univariate analysis } & \multicolumn{2}{|c|}{ Multivariate analysis } \\
\hline & HR (95\% CI) & $P$-value & HR (95\% Cl) & $P$-value \\
\hline \multicolumn{5}{|l|}{ Race } \\
\hline White & Reference & & Reference & \\
\hline Black & $1.68(1.07-2.62)$ & $0.02 *$ & $1.73(1.01-2.96)$ & $0.04 *$ \\
\hline Other & I (0.43-2.35) & I & $0.83(0.33-2.1)$ & 0.69 \\
\hline \multicolumn{5}{|c|}{ Marital status } \\
\hline Not married & Reference & & Reference & \\
\hline Married & $0.62(0.38-1)$ & $0.049 *$ & $0.72(0.43-1.22)$ & 0.22 \\
\hline Unknown & $1.77(0.8-3.91)$ & 0.16 & $1.05(0.39-2.77)$ & 0.93 \\
\hline \multicolumn{5}{|l|}{ Grade } \\
\hline I and II & Reference & & Reference & \\
\hline III & $1.86(1.11-3.11)$ & $0.02 *$ & I.59 (0.9-2.83) & 0.11 \\
\hline IV & $0.94(0.4-2.2)$ & 0.89 & $1.02(0.4 \mathrm{I}-2.54)$ & 0.97 \\
\hline Unknown & $2.11(1.13-3.96)$ & $0.02 *$ & $1.7(0.8 \mathrm{I}-3.58)$ & 0.16 \\
\hline \multicolumn{5}{|c|}{ Tumor size, cm } \\
\hline$\leq 2$ & Reference & & & \\
\hline$>2$ and $\leq 5$ & I.2I (0.57-2.56) & 0.62 & & \\
\hline$>5$ & $0.92(0.34-2.55)$ & 0.88 & & \\
\hline Unknown & I.I5 (0.58-2.27) & 0.7 & & \\
\hline \multicolumn{5}{|c|}{ Positive-node status } \\
\hline 0 & Reference & & & \\
\hline$I-3$ & $\mathrm{I} .29(0.6 \mathrm{I}-2.7)$ & 0.51 & & \\
\hline$>3$ & - & - & & \\
\hline Unknown & $1.26(0.72-2.23)$ & 0.42 & & \\
\hline \multicolumn{5}{|c|}{ AJCC stage } \\
\hline I & Reference & & Reference & \\
\hline II & $0.44(0.25-0.77)$ & $<0.00 I^{*}$ & $0.77(0.1-5.89)$ & 0.8 \\
\hline III and IV & $0.61(0.35-1.05)$ & 0.08 & $1.06(0.18-6.27)$ & 0.94 \\
\hline Unknown & $1.2(0.75-1.92)$ & 0.44 & $0.6(0.08-4.32)$ & 0.62 \\
\hline \multicolumn{5}{|l|}{ pT stage } \\
\hline TO and TI & Reference & & Reference & \\
\hline $\mathrm{T} 2$ & I (0.5-2.04) & 0.99 & $1.43(0.22-9.1)$ & 0.71 \\
\hline T3 & $2.09(|| 7-3.7 \mid)$. & $0.01 *$ & $1.35(0.26-7.08)$ & 0.73 \\
\hline $\mathrm{T} 4$ and $\mathrm{TX}$ & $2.04(1.09-3.81)$ & $0.03 *$ & $1.35(0.25-7.23)$ & 0.73 \\
\hline \multicolumn{5}{|l|}{ pN stage } \\
\hline No & Reference & & Reference & \\
\hline NI & $1.07(0.56-2.04)$ & 0.83 & $0.78(0.32-1.93)$ & 0.6 \\
\hline N2 & $2.24(1.13-4.43)$ & $0.02 *$ & $1.33(0.6 \mid-2.91)$ & 0.48 \\
\hline NX & I.3। (0.6-2.87) & 0.5 & $0.89(0.21-3.83)$ & 0.88 \\
\hline \multicolumn{5}{|l|}{ pM stage } \\
\hline MO & Reference & & Reference & \\
\hline MI & $4.2(2.4-7.37)$ & $<0.00 I^{*}$ & $2.3(1.07-4.93)$ & $0.03 *$ \\
\hline$M X$ & I.3। (0.48-3.6) & 0.6 & $1.97(0.36-10.9)$ & 0.44 \\
\hline \multicolumn{5}{|l|}{ Surgery } \\
\hline No & Reference & & Reference & \\
\hline Yes & $0.49(0.32-0.75)$ & $0.001 *$ & $0.56(0.33-0.93)$ & $0.03 *$ \\
\hline \multicolumn{5}{|l|}{ Radiation } \\
\hline Yes & Reference & & & \\
\hline No & $1.17(0.76-1.81)$ & 0.47 & & \\
\hline \multicolumn{5}{|c|}{ Histological type } \\
\hline SCC, NOS & Reference & & & \\
\hline TCC, NOS & $\mathrm{I} .05(0.6 \mathrm{I}-\mathrm{I} .83)$ & 0.85 & & \\
\hline Ac, NOS & $\mathrm{I} .34(0.8-2.27)$ & 0.27 & & \\
\hline
\end{tabular}

Note: $* P<0.05$.

Abbreviations: AJCC, American Joint Committee on Cancer; SCC, squamous cell carcinoma; TCC, transitional cell carcinoma; Ac, adenocarcinoma; NOS, not otherwise specified.
Table 3 Univariate and multivariate analysis of cancer-specific survival in women

\begin{tabular}{|c|c|c|c|c|}
\hline & \multicolumn{2}{|c|}{ Univariate analysis } & \multicolumn{2}{|c|}{ Multivariate analysis } \\
\hline & HR (95\% Cl) & $P$-value & HR (95\% CI) & $P$-value \\
\hline \multicolumn{5}{|c|}{ Year of diagnosis } \\
\hline 2004-2008 & Reference & & & \\
\hline $2009-2013$ & $0.9(0.53-\mid .5 I)$ & 0.68 & & \\
\hline \multicolumn{5}{|c|}{ Age at diagnosis, years } \\
\hline $0-54$ & Reference & & & \\
\hline $55-64$ & $0.74(0.35-1.55)$ & 0.42 & & \\
\hline $65-74$ & $0.72(0.33-1.59)$ & 0.42 & & \\
\hline $75-84$ & $1.28(0.62-2.63)$ & 0.51 & & \\
\hline $85+$ & $1.08(0.45-2.62)$ & 0.86 & & \\
\hline \multicolumn{5}{|l|}{ Race } \\
\hline White & Reference & & Reference & \\
\hline Black & $1.94(1.16-3.22)$ & $0.01 *$ & $\mathrm{I} .85(\mathrm{I} .0 \mathrm{I}-3.39)$ & $0.048^{*}$ \\
\hline Other & $1.23(0.48-3.15)$ & 0.67 & $0.95(0.33-2.7 \mathrm{I})$ & 0.92 \\
\hline \multicolumn{5}{|c|}{ Marital status } \\
\hline Not married & Reference & & Reference & \\
\hline Married & $0.48(0.27-0.86)$ & $0.01 *$ & $0.56(0.3-1.06)$ & 0.07 \\
\hline Unknown & $1.49(0.59-3.78)$ & 0.4 & $0.84(0.27-2.61)$ & 0.77 \\
\hline \multicolumn{5}{|l|}{ Grade } \\
\hline I and II & Reference & & Reference & \\
\hline III & $1.97(1.07-3.63)$ & $0.03 *$ & $1.64(0.83-3.22)$ & 0.15 \\
\hline IV & $1.33(0.55-3.23)$ & 0.53 & $1.55(0.59-4.05)$ & 0.37 \\
\hline Unknown & $2.23(1.07-4.65)$ & $0.03 *$ & $1.61(0.67-3.88)$ & 0.28 \\
\hline \multicolumn{5}{|c|}{ Tumor size, cm } \\
\hline$\leq 2$ & Reference & & & \\
\hline$>2$ and $\leq 5$ & $1.21(0.49-2.97)$ & 0.68 & & \\
\hline$>5$ & $0.7(0.18-2.69)$ & 0.6 & & \\
\hline Unknown & $1.41(0.63-3.14)$ & 0.41 & & \\
\hline \multicolumn{5}{|c|}{ Positive-node status } \\
\hline 0 & Reference & & & \\
\hline $\mathrm{I}-3$ & $1.64(0.72-3.73)$ & 0.23 & & \\
\hline$>3$ & - & - & & \\
\hline Unknown & $1.26(0.65-2.46)$ & 0.49 & & \\
\hline \multicolumn{5}{|c|}{ AJCC stage } \\
\hline I & Reference & & Reference & \\
\hline II & $1.5(0.5-4.47)$ & 0.47 & $1.51(0.17-13.58)$ & 0.71 \\
\hline III and IV & $3.06(1.29-7.27)$ & $0.01 *$ & $2.6(0.38-17.55)$ & 0.33 \\
\hline Unknown & $2.42(0.77-7.64)$ & 0.13 & $1.58(0.17-15.11)$ & 0.69 \\
\hline \multicolumn{5}{|l|}{ PT stage } \\
\hline $\mathrm{TO}$ and $\mathrm{TI}$ & Reference & & Reference & \\
\hline $\mathrm{T} 2$ & $1.6(0.65-3.94)$ & 0.31 & $1.2(0.18-7.85)$ & 0.85 \\
\hline T3 & $3.56(1.67-7.59)$ & $<0.00 I^{*}$ & $1.14(0.2 \mathrm{I}-6.28)$ & 0.88 \\
\hline $\mathrm{T} 4$ and $\mathrm{TX}$ & $3.56(1.59-7.96)$ & $<0.00 I^{*}$ & $1.09(0.19-6.2)$ & 0.92 \\
\hline \multicolumn{5}{|l|}{ pN stage } \\
\hline No & Reference & & Reference & \\
\hline $\mathrm{NI}$ & $1.56(0.8-3.04)$ & 0.19 & $0.91(0.35-2.32)$ & 0.84 \\
\hline N2 & $2.79(1.34-5.82)$ & $0.01 *$ & $1.49(0.64-3.46)$ & 0.35 \\
\hline NX & $1.33(0.52-3.37)$ & 0.55 & $0.32(0.03-3.29)$ & 0.34 \\
\hline \multicolumn{5}{|l|}{ pM stage } \\
\hline MO & Reference & & Reference & \\
\hline MI & $4.01(2.1-7.64)$ & $<0.00 I^{*}$ & $2.39(\mathrm{I} .02-5.6 \mathrm{I})$ & $0.04 *$ \\
\hline$M X$ & $1.75(0.63-4.85)$ & 0.28 & $6.2(0.58-66.3)$ & 0.13 \\
\hline \multicolumn{5}{|l|}{ Surgery } \\
\hline No & Reference & & Reference & \\
\hline Yes & $0.58(0.35-0.96)$ & $0.03^{*}$ & $0.7(0.38-1.29)$ & 0.25 \\
\hline
\end{tabular}


Table 3 (Continued)

\begin{tabular}{|c|c|c|c|c|}
\hline & \multicolumn{2}{|c|}{ Univariate analysis } & \multicolumn{2}{|c|}{ Multivariate analysis } \\
\hline & HR (95\% Cl) & $P$-value & HR (95\% Cl) & $P$-value \\
\hline \multicolumn{5}{|l|}{ Radiation } \\
\hline Yes & Reference & & & \\
\hline No & $1.22(0.74-2.02)$ & 0.43 & & \\
\hline \multicolumn{5}{|c|}{ Histological type } \\
\hline SCC, NOS & Reference & & & \\
\hline TCC, NOS & $1.2(0.6 \mathrm{I}-2.36)$ & 0.6 & & \\
\hline Ac, NOS & $1.83(0.98-3.39)$ & 0.06 & & \\
\hline
\end{tabular}

Note: $* p<0.05$.

Abbreviations: AJCC, American Joint Committee on Cancer; SCC, squamous cell carcinoma; TCC, transitional cell carcinoma; Ac, adenocarcinoma; NOS, not otherwise specified.

We found that race, surgery, age, AJCC stage, and pM stage were significant prognostic factors of OS. pM stage was a significant prognostic factor of CSS. We focused on sex and histological type to identify factors that can be exploited to improve patient outcomes.

Our findings illuminate the unique clinicopathological characteristics of women and reveal that marital status, AJCC stage, $\mathrm{pT}$ stage, $\mathrm{pN}$ stage, $\mathrm{pM}$ stage, and surgery were significantly associated with OS and CSS in women and men. In contrast, we did not detect significant sex-specific differences in OS or CSS. However, Ac was associated with worse prognosis of CSS only in women. Further, TCC predicted worse prognosis for men only for CSS compared with Ac or SCC.

A comprehensive review of the incidence of PUC stratified according to sex using the SEER database found that the incidence of PUC was higher in men, although differences in survival stratified according to sex were not detected. ${ }^{13}$ Our present study shows that the incidence of PUC was higher in men (63.4\%), which is consistent with findings that $66.6 \%$ of men have a threefold higher incidence of PUC compared with women. ${ }^{13}$ In contrast, studies of 344 patients with PUC included in European cancer registries ${ }^{14}$ and a multi-institutional study of 154 patients with $\mathrm{PUC}^{6}$ did not detect a difference in OS between women and men. The median OS values of men and women were 21 months and 20 months, respectively, which supports the conclusion that women and men with PUC may experience similar durations of survival.

The main histological types of PUC were investigated in the present study. In comparison, studies of 25 series of patients with PUC in the US found that the incidence of SCC was $44.9 \%$ in women and $68 \%$ in men. ${ }^{13}$ Further, this study found that the incidence of TCC was $21.7 \%$ in women and $17.5 \%$ in men, and the incidence of Ac $26.8 \%$ in women and $4.6 \%$ in men. ${ }^{13}$ However, we show here that the incidence of SCC
Table 4 Univariate and multivariate analysis of overall survival in men

\begin{tabular}{|c|c|c|c|c|}
\hline & \multicolumn{2}{|c|}{ Univariate analysis } & \multicolumn{2}{|c|}{ Multivariate analysis } \\
\hline & HR (95\% Cl) & $P$-value & HR (95\% Cl) & $P$-value \\
\hline \multicolumn{5}{|c|}{ Year of diagnosis } \\
\hline 2004-2008 & Reference & & Reference & \\
\hline $2009-2013$ & $0.66(0.46-0.95)$ & $0.03 *$ & $0.8(0.55-1.17)$ & 0.25 \\
\hline \multicolumn{5}{|c|}{ Age at diagnosis, years } \\
\hline $0-54$ & Reference & & Reference & \\
\hline $55-64$ & $0.72(0.42-1.24)$ & 0.23 & $0.96(0.53-1.72)$ & 0.88 \\
\hline $65-74$ & $0.91(0.54-1.5 \mathrm{I})$ & 0.71 & $1.31(0.74-2.33)$ & 0.36 \\
\hline $75-84$ & $1.85(1.17-2.93)$ & $0.01 *$ & $2.95(1.69-5.15)$ & $<0.001^{*}$ \\
\hline $85+$ & $1.75(1.01-3.05)$ & $0.046^{*}$ & $3.9(1.98-7.67)$ & $<0.00 I^{*}$ \\
\hline \multicolumn{5}{|l|}{ Race } \\
\hline White & $1.63(0.91-2.91)$ & 0.1 & & \\
\hline Black & $0.86(0.33-2.23)$ & 0.76 & & \\
\hline Other & $1.68(0.79-3.57)$ & 0.18 & & \\
\hline \multicolumn{5}{|c|}{ Marital status } \\
\hline Not married & Reference & & Reference & \\
\hline Married & $0.71(0.51-0.99)$ & $0.04 *$ & $0.83(0.58-1.2)$ & 0.32 \\
\hline Unknown & $0.41(0.15-1.12)$ & 0.08 & $0.33(0.11-0.98)$ & $0.045^{*}$ \\
\hline \multicolumn{5}{|l|}{ Grade } \\
\hline I and II & Reference & & & \\
\hline III & $1.41(0.92-2.15)$ & 0.11 & & \\
\hline IV & I.II (0.69-I.79) & 0.67 & & \\
\hline Unknown & $1.41(0.85-2.35)$ & 0.18 & & \\
\hline \multicolumn{5}{|c|}{ Tumor size, cm } \\
\hline$\leq 2$ & Reference & & & \\
\hline$>2$ and $\leq 5$ & $0.91(0.5-1.63)$ & 0.74 & & \\
\hline$>5$ & $0.77(0.38-1.59)$ & 0.48 & & \\
\hline Unknown & $0.97(0.57-1.65)$ & 0.91 & & \\
\hline \multicolumn{5}{|c|}{ Positive-node status } \\
\hline 0 & Reference & & & \\
\hline $1-3$ & $0.69(0.32-1.46)$ & 0.33 & & \\
\hline$>3$ & $0.96(0.32-2.89)$ & 0.95 & & \\
\hline Unknown & $0.86(0.51-1.46)$ & 0.58 & & \\
\hline \multicolumn{5}{|l|}{ AJCC stage } \\
\hline I & Reference & & Reference & \\
\hline II & $1.39(0.82-2.36)$ & 0.22 & $2.13(0.77-5.9)$ & 0.15 \\
\hline III and IV & $1.87(1.08-3.25)$ & $0.03 *$ & $3.46(1.36-8.82)$ & $0.01 *$ \\
\hline Unknown & $2.3(1.31-4.04)$ & $<0.001 *$ & $3.01(1.09-8.3)$ & $0.03 *$ \\
\hline \multicolumn{5}{|l|}{ pT stage } \\
\hline $\mathrm{TO}$ and $\mathrm{TI}$ & Reference & & Reference & \\
\hline $\mathrm{T} 2$ & $1.4 \mid(0.9 \mid-2.19)$ & 0.12 & $0.78(0.33-1.85)$ & 0.57 \\
\hline T3 & $2.26(1.39-3.67)$ & $<0.001 *$ & $0.79(0.34-1.79)$ & 0.57 \\
\hline $\mathrm{T} 4$ and $\mathrm{TX}$ & $2.45(1.56-3.84)$ & $<0.001 *$ & $0.91(0.43-1.94)$ & 0.8 \\
\hline \multicolumn{5}{|l|}{ pN stage } \\
\hline No & Reference & & Reference & \\
\hline $\mathrm{NI}$ & $1.47(0.92-2.34)$ & 0.1 & $0.69(0.37-1.27)$ & 0.23 \\
\hline N2 & $1.37(0.76-2.44)$ & 0.29 & $0.91(0.44-1.88)$ & 0.8 \\
\hline$N X$ & $1.98(1.22-3.22)$ & $0.01 *$ & $0.58(0.27-1.24)$ & 0.16 \\
\hline \multicolumn{5}{|l|}{ pM stage } \\
\hline Mo & Reference & & Reference & \\
\hline MI & $5.5(3.64-8.33)$ & $<0.001 *$ & $4.38(2.5-7.67)$ & $<0.001^{*}$ \\
\hline$M X$ & $2.14(1.2-3.8 \mathrm{I})$ & $0.01 *$ & $3.14(1.19-8.24)$ & $0.02 *$ \\
\hline \multicolumn{5}{|l|}{ Surgery } \\
\hline No & Reference & & Reference & \\
\hline Yes & $0.62(0.44-0.88)$ & $0.01 *$ & $0.7(0.46-1.06)$ & 0.09 \\
\hline
\end{tabular}


Table 4 (Continued)

\begin{tabular}{|c|c|c|c|c|}
\hline & \multicolumn{2}{|c|}{ Univariate analysis } & \multicolumn{2}{|c|}{ Multivariate analysis } \\
\hline & HR (95\% CI) & $P$-value & HR (95\% Cl) & $P$-value \\
\hline \multicolumn{5}{|l|}{ Radiation } \\
\hline Yes & Reference & & & \\
\hline No & $0.74(I-0.39)$ & 0.39 & & \\
\hline \multicolumn{5}{|c|}{ Histological type } \\
\hline SCC, NOS & Reference & & Reference & \\
\hline TCC, NOS & $1.78(1.25-2.52)$ & $<0.00 I^{*}$ & $1.17(0.78-1.77)$ & 0.45 \\
\hline Ac, NOS & $1.15(0.6 \mathrm{I}-2.16)$ & 0.67 & $0.8 I(0.4 I-I .6)$ & 0.55 \\
\hline
\end{tabular}

Note: $* p<0.05$.

Abbreviations: AJCC, American Joint Committee on Cancer; SCC, squamous cell carcinoma; TCC, transitional cell carcinoma; Ac, adenocarcinoma; NOS, not otherwise specified.

was $31.3 \%$ in women and $39.4 \%$ in men, the incidence of TCC was $32.5 \%$ in women and $51.6 \%$ in men, and the incidence of Ac was $36.1 \%$ in women and $9.1 \%$ in men. The most common histological type was TCC, which is consistent with the study cited earlier. ${ }^{13}$ However, our results are inconsistent with findings that TCC occurs more frequently among men than women $(51.6 \% \mathrm{vs} 32.5 \%),{ }^{15}$ which is inconsistent with the results of the study cited $(17.5 \%$ vs $21.7 \%) .{ }^{13}$ We show here that there were no significant differences in survival among patients with SCC, TCC, or Ac. Surprisingly, CSS was significantly worse for women with Ac, which is consistent with a study of 869 women with $\mathrm{PUC}^{11}$ and may be explained by differences in sex-specific anatomy, tumor biology, tumor location, positive lymph-node status, and marital status. Further, men with Ac experience longer survival, ${ }^{12}$ which supports our results.

The 5-year OS rates of women with PUC with SCC, TCC, or Ac were $64 \%, 61 \%$, and $31 \%$, respectively, indirectly indicating that TCC is associated with worse survival compared with Ac. ${ }^{5}$ We show here that men with TCC experienced significantly worse survival compared with Ac, which is consistent with findings that 2,065 men with PUC with Ac survived longer compared with those with TCC. ${ }^{12}$ However, we did not detect differences in the survival of women with TCC or Ac, which is inconsistent with a previous study. ${ }^{5}$ We also demonstrate that men with SCC experienced significantly better survival compared with TCC, which is consistent with findings that SCC (69\%) possesses the highest 5 -year relative survival rate compared with TCC (52\%). ${ }^{14}$

Racial characteristics are considered important factors affecting treatment strategies and oncological outcomes of patients with urological tumors. ${ }^{16,17}$ Disparities were also associated with the quality of medical care, particularly in the US, for economically disadvantaged patients. However, the roles of racial disparities in influencing the outcomes of patients with PUC have been insufficiently characterized,
Table 5 Univariate and multivariate analysis of cancer-specific survival in men

\begin{tabular}{|c|c|c|c|c|}
\hline & \multicolumn{2}{|c|}{ Univariate analysis } & \multicolumn{2}{|c|}{ Multivariate analysis } \\
\hline & HR (95\% Cl) & $P$-value & HR (95\% Cl) & $P$-value \\
\hline \multicolumn{5}{|c|}{ Year of diagnosis } \\
\hline 2004-2008 & Reference & & & \\
\hline $2009-2013$ & $0.66(0.43-1)$ & 0.05 & & \\
\hline \multicolumn{5}{|c|}{ Age at diagnosis, years } \\
\hline $0-54$ & Reference & & & \\
\hline $55-64$ & $0.59(0.32-1.08)$ & 0.09 & & \\
\hline $65-74$ & $0.73(0.42-1.3)$ & 0.29 & & \\
\hline $75-84$ & I.2 (0.7I-2.0I) & 0.5 & & \\
\hline $85+$ & $1.09(0.56-2.12)$ & 0.79 & & \\
\hline \multicolumn{5}{|l|}{ Race } \\
\hline White & Reference & & & \\
\hline Black & $1.28(0.75-2.18)$ & 0.36 & & \\
\hline Other & $0.65(0.24-1.76)$ & 0.39 & & \\
\hline \multicolumn{5}{|c|}{ Marital status } \\
\hline Not married & Reference & & Reference & \\
\hline Married & $0.62(0.42-0.91)$ & $0.01 *$ & $0.77(0.5 \mathrm{I}-\mathrm{I} . \mathrm{I7})$ & 0.22 \\
\hline Unknown & $0.25(0.06-1.05)$ & 0.06 & $0.22(0.05-0.97)$ & $0.045^{*}$ \\
\hline \multicolumn{5}{|l|}{ Grade } \\
\hline I and II & Reference & & Reference & \\
\hline III & $2.04(1.2-3.47)$ & $0.0 I^{*}$ & $\mathrm{I} .44(0.78-2.67)$ & 0.24 \\
\hline IV & $1.42(0.78-2.58)$ & 0.25 & $0.83(0.39-1.79)$ & 0.64 \\
\hline Unknown & $1.42(0.73-2.76)$ & 0.31 & $1.05(0.49-2.25)$ & 0.9 \\
\hline \multicolumn{5}{|c|}{ Tumor size, $\mathrm{cm}$} \\
\hline$\leq 2$ & Reference & & & \\
\hline$>2$ and $\leq 5$ & $0.84(0.42-1.66)$ & 0.61 & & \\
\hline$>5$ & $0.72(0.31-1.67)$ & 0.45 & & \\
\hline Unknown & $0.89(0.48-1.65)$ & 0.71 & & \\
\hline \multicolumn{5}{|c|}{ Positive-node status } \\
\hline 0 & Reference & & & \\
\hline $1-3$ & $0.72(0.3 \mid-1.67)$ & 0.45 & & \\
\hline$>3$ & $1.14(0.37-3.54)$ & 0.82 & & \\
\hline Unknown & $0.74(0.4-1.35)$ & 0.33 & & \\
\hline \multicolumn{5}{|l|}{ AJCC stage } \\
\hline I & Reference & & Reference & \\
\hline II & $2.12(1-4.49)$ & $0.049 *$ & $2.09(0.65-6.69)$ & 0.22 \\
\hline III and IV & $3.22(1.53-6.78)$ & $<0.00 I^{*}$ & $4.73(1.59-14.04)$ & $0.01 *$ \\
\hline Unknown & $3.83(1.79-8.19)$ & $<0.00 I^{*}$ & $2.93(0.9-9.52)$ & 0.07 \\
\hline \multicolumn{5}{|l|}{ pT stage } \\
\hline $\mathrm{TO}$ and $\mathrm{TI}$ & Reference & & Reference & \\
\hline $\mathrm{T} 2$ & $1.87(1.07-3.25)$ & $0.03^{*}$ & $0.98(0.4 \mathrm{I}-2.35)$ & 0.96 \\
\hline T3 & $2.97(1.63-5.42)$ & $<0.00$ I* & $0.7(0.29-|.7|)$ & 0.44 \\
\hline $\mathrm{T} 4$ and $\mathrm{TX}$ & $3.33(1.9-5.84)$ & $<0.00 I^{*}$ & $0.96(0.44-2.14)$ & 0.93 \\
\hline \multicolumn{5}{|l|}{ pN stage } \\
\hline No & Reference & & Reference & \\
\hline NI & $1.94(1.16-3.24)$ & $0.01 *$ & $0.65(0.33-1.27)$ & 0.2 \\
\hline N2 & $1.9(1.02-3.53)$ & $0.04 *$ & $0.9 \mathrm{I}(0.4 \mathrm{I}-2)$ & 0.81 \\
\hline NX & $2.22(1.26-3.9 \mid)$ & $0.01 *$ & $0.94(0.4 I-2.15)$ & 0.88 \\
\hline \multicolumn{5}{|l|}{ pM stage } \\
\hline Mo & Reference & & Reference & \\
\hline MI & $7.5(4.78-|| .77)$ & $<0.00 I^{*}$ & $3.52(2.01-6.16)$ & $<0.00 I^{*}$ \\
\hline$M X$ & $2.24(1.12-4.48)$ & $0.02 *$ & $2.12(0.74-6.07)$ & 0.16 \\
\hline \multicolumn{5}{|l|}{ Surgery } \\
\hline No & Reference & & Reference & \\
\hline Yes & $0.55(0.37-0.82)$ & $<0.00 I^{*}$ & $0.65(0.4 \mid-I .04)$ & 0.07 \\
\hline
\end{tabular}


Table 5 (Continued)

\begin{tabular}{|c|c|c|c|c|}
\hline & \multicolumn{2}{|c|}{ Univariate analysis } & \multicolumn{2}{|c|}{ Multivariate analysis } \\
\hline & HR (95\% Cl) & $P$-value & HR (95\% Cl) & $P$-value \\
\hline \multicolumn{5}{|l|}{ Radiation } \\
\hline Yes & Reference & & & \\
\hline No & $1.03(0.66-1.62)$ & 0.88 & & \\
\hline \multicolumn{5}{|c|}{ Histological type } \\
\hline SCC, NOS & Reference & & Reference & \\
\hline TCC, NOS & $1.62(1.08-2.42)$ & $0.02 *$ & $1.72(I-2.95)$ & 0.05 \\
\hline Ac, NOS & $0.62(0.24-1.57)$ & 0.31 & $0.78(0.29-2.08)$ & 0.62 \\
\hline
\end{tabular}

Note: $* p<0.05$.

Abbreviations: AJCC, American Joint Committee on Cancer; SCC, squamous cell carcinoma; TCC, transitional cell carcinoma; Ac, adenocarcinoma; NOS, not otherwise specified.

and this subject is thus controversial. ${ }^{11,16-18}$ For example, the survival of black women with PUC is significantly shorter. ${ }^{19}$ However, the survival of men with PUC has not been studied. Our present study of racial differences among all patients with PUC shows that black women experienced significantly shorter OS. However, there was no significant difference in survival between men and women associated with race, which may be attributed to tumor biology or access to treatment. ${ }^{11}$

Our study has several limitations. First, chemotherapy data are unavailable from the SEER database. Moreover, studies of small numbers of patients and case reports ${ }^{20,21}$ indicate that chemotherapy is potentially beneficial. ${ }^{19}$ Second, details of radiation therapy and surgery, which can vary significantly among different institutions, are not available from the SEER database. Third, the percentage of men with PUC was higher compared with women, which may introduce bias, although there was no significant sex-specific difference associated with OS. Fourth, it was a retrospective study. Fifth, we did not consider lifestyle differences that may contribute to outcomes. For example, the prevalence of tobacco use by men was more frequent. Tobacco use is a strong risk factor for tumors of the bladder and upper urinary tract. ${ }^{22}$ Moreover, the urethra has the same histological features as the bladder and upper urinary tract, which indicates a relationship between tobacco use and UC. ${ }^{13,23}$

\section{Conclusion}

Women with PUC have unique clinicopathological characteristics. Black race and lack of surgical intervention were associated with shorter OS of women. Age $>75$ years and advanced AJCC stage were associated with increased mortality of men. Advanced AJCC stage was associated with shortened CSS only in men. Women with Ac experienced poor CSS compared with men. Men with TCC experienced worse CSS compared with those with Ac or SCC.

\section{Acknowledgments}

This study was supported by the Young and Middle-Aged Scholars Program of Health and Family Planning Commission of Fujian Province, China (grant 2015-ZQN-JC-20), and the Funds for Creative Program of Health and Family Planning Commission of Fujian Province, China (grant 2016-CX-27).

\section{Disclosure}

The authors report no conflicts of interest in this work.

\section{References}

1. Gakis G, Morgan TM, Daneshmand S, et al. Impact of perioperative chemotherapy on survival in patients with advanced primary urethral cancer: results of the international collaboration on primary urethral carcinoma. Ann Oncol. 2015;26:1754-1759.

2. Gakis G, Witjes JA, Compérat E, et al. EAU guidelines on primary urethral carcinoma. Eur Oncol. 2013;64:823-830.

3. Lughezzani G, Sun M, Perrotte P, et al. Gender-related differences in patients with stage I to III upper tract urothelial carcinoma: results from the Surveillance, Epidemiology, and End Results database. Urology. 2010;75:321-327.

4. Kohi MP. Gender-related differences in hepatocellular carcinoma: does sex matter? J Vasc Interv Radiol. 2016;27:1338-1341.

5. Derksen JW, Visser O, de la Rivière GB, Meuleman EJ, Heldeweg EA, Lagerveld BW. Primary urethral carcinoma in females: an epidemiologic study on demographical factors, histological types, tumour stage and survival. World J Urol. 2013;31:147-153.

6. Gakis G, Morgan TM, Efstathiou JA, et al. Prognostic factors and outcomes in primary urethral cancer: results from the international collaboration on primary urethral carcinoma. World J Urol. 2016;34:97-103.

7. Berjeaut RH, Persaud MD, Sopko N, Burnett AL. Urethral carcinoma in situ: recognition and management. Int Urol Nephrol. 2017;49:637-641.

8. Harlan LC, Hankey BF. The Surveillance, Epidemiology, and End Results program database as a resource for conducting descriptive epidemiologic and clinical studies. J Clin Oncol. 2003;21:2232-2233.

9. Eminaga O, Akbarov I, Wille S, Engelmann U. Does postoperative radiation therapy impact survival in non-metastatic sarcomatoid renal cell carcinoma? A SEER-based study. Int Urol Nephrol. 2015;47:1653-1663.

10. Wu YP, Lin TT, Chen SH, et al. Comparison of the efficacy and feasibility of en bloc transurethral resection of bladder tumor versus conventional transurethral resection of bladder tumor: a meta-analysis. Medicine (Baltimore). 2016;95:e5372.

11. Sui W, Choudhury AR, Wenske S, et al. Outcomes and prognostic factors of primary urethral cancer. Urology. 2017;100:180-186.

12. Rabbani F. Prognostic factors in male urethral cancer. Cancer. 2011; 117:2426-2434.

13. Swartz MA, Porter MP, Lin DW, Weiss NS. Incidence of primary urethral carcinoma in the United States. Urology. 2006;68:1164-1168.

14. Visser O, Adolfsson J, Rossi S, et al. Incidence and survival of rare urogenital cancers in Europe. Eur J Cancer. 2012;48:456-464.

15. Dayyani F, Hoffman K, Eifel P, et al. Management of advanced primary urethral carcinomas. BJU Int. 2014;114:25-31.

16. Jalloh M, Myers F, Cowan JE, Carroll PR, Cooperberg MR. Racial variation in prostate cancer upgrading and upstaging among men with low-risk clinical characteristics. Eur Oncol. 2015;67:451-457.

17. Feibus AH, Levy J, McCaslin IR, et al. Racial variation in prostate needle biopsy templates directed anterior to the peripheral zone. Urol Oncol. 2016;34:336.e1-336.e6.

18. McGinley KF, Tay KJ, Moul JW. Prostate cancer in men of African origin. Nat Rev Urol. 2016;13:99-107.

19. Champ CE, Hegarty SE, Shen X, et al. Prognostic factors and outcomes after definitive treatment of female urethral cancer: a population-based analysis. Urology. 2012;80:374-381. 
20. Ji GH, Qian YF. Successful treatment of metastatic upper tract urothelial carcinoma with vemurafenib: case report. Clin Genitourin Cancer. Epub 2016 Nov 30.

21. Krawczyk M, Zimmermann S, Vidacek D, Lammert F. Intraperitoneal catumaxomab therapy in a cirrhotic patient with malignant ascites due to urethelial [sic] carcinoma: a case report. Onkologie. 2012;35:592-594.
22. van Osch FH, Jochems SH, van Schooten FJ, Bryan RT, Zeegers MP. Significant role of lifetime cigarette smoking in worsening bladder cancer and upper tract urothelial carcinoma prognosis: a meta-analysis. J Urol. 2016;195:872-879.

23. Vineis $\mathrm{P}$, Alavanja $\mathrm{M}$, Buffler $\mathrm{P}$, et al. Tobacco and cancer: recent epidemiological evidence. J Natl Cancer Inst. 2004;96:99-106.

\section{Publish your work in this journal}

OncoTargets and Therapy is an international, peer-reviewed, open access journal focusing on the pathological basis of all cancers, potential targets for therapy and treatment protocols employed to improve the management of cancer patients. The journal also focuses on the impact of management programs and new therapeutic agents and protocols on

\section{Dovepress}

patient perspectives such as quality of life, adherence and satisfaction. The manuscript management system is completely online and includes a very quick and fair peer-review system, which is all easy to use. Visit http://www.dovepress.com/testimonials.php to read real quotes from published authors.

Submit your manuscript here: http://www.dovepress.com/oncotargets-and-therapy-journal 